\title{
Larval settlement, post-settlement growth and secondary production of the Florida lancelet (= amphioxus) Branchiostoma floridae
}

\author{
M. D. Stokes* \\ Marine Biology Research Division, Scripps Institution of Oceanography, La Jolla, California 92093-0202, USA
}

\begin{abstract}
A population of Branchiostoma floridae in Tampa Bay, Florida, USA was sieved from the substratum frequently (often daily) from June 1992 through September 1994. Body lengths were measured for 54264 juvenile and adult lancelets. The breeding season lasted each year from early May through early September, and newly metamorphosed lancelets settled as juveniles from late May through mid October; during this period of the year, distinct settlements occurred approximately every 1 to $3 \mathrm{wk}$. Post-settlement growth was followed as changes in modal length on size-frequency histograms. Changes in cohort growth over this period were compared to several different simple and seasonally oscillating growth models. The von Bertalanffy function, in simple and oscillating forms, provided the best estimates of lancelet growth. The lancelets grew in summer (almost $0.5 \mathrm{~mm} \mathrm{~d}^{-1}$ in recently settled juveniles), but growth slowed and almost ceased during winter. $B$. floridae can live at least 2 yr and can reach a maximum length of $58 \mathrm{~mm}$. The maximal secondary production was $61.53 \mathrm{~g} \mathrm{~m}^{-2} \mathrm{yr}^{-1}$ (ash-free dry weight) and the production to biomass ratio was 11.64. Population densities at the study site ranged from about 100 to 1200 lancelets $\mathrm{m}^{-2}$.
\end{abstract}

KEY WORDS: Lancelet Amphioxus - Branchiostoma floridae - Growth - Production - Breeding season Larval settlement

\section{INTRODUCTION}

The subphylum Cephalochordata of the phylum Chordata consists of approximately 25 living species of lancelet (= amphioxus) (Poss \& Boschung 1994), which are widely distributed in tropical and temperate seas. Cephalochordates are probably the closest living invertebrate relatives of vertebrates (Wada \& Satoh 1994), and lancelets have long occupied a key place in discussions on the origin of vertebrates.

A thorough understanding of the ecology of larval and adult cephalochordates is needed to reconstruct plausible scenarios of the life style of the proximate invertebrate ancestor of the vertebrates (Willey 1894. Berrill 1955, Gans 1989) and also to obtain the embryos and larvae needed for developmental evolutionary studies (Holland et al. 1992, Garcia-Fernàndez \& Hol-

•E-mail:mstokes@sdcc3.ucsd.edu land 1994). In recent years, one species, Branchiostoma floridae, has become especially useful for studies on developmental evolution and larval biology because its eggs can be artificially fertilized (Holland \& Holland 1989j and its developmental stages can be raised in the laboratory (Stokes \& Holland 1995a). The latter study included a description of growth rates from fertilization through the end of metamorphosis (the first 3 to $4 \mathrm{wk}$ of life at field temperatures).

To date, the only comprehensive information on lancelet ecology pertains to an estuarine population that was unusual in that it was entirely killed by torrential rains each spring (Webb 1958). Other ecological studies were either anecdotal or hampered by infrequent sampling intervals (Wells 1926. Chin 1941 , Courtney \& Webb 1964, Dawson 1965, Pierce 1965, Frankenberg 1968, Nelson 1969, McShine 1971, Courtney 1975, Azariah 1994, Wu et al. 1994). Therefore, the present study examines aspects of population dynamics of post-metamorphic Florida lancelets Bran- 
chiostoma floridae living in Tampa Bay, USA. This population is generally representative of lancelets as having a life span of several years and is particularly amenable to study since $B$. floridae can be collected at a depth of about 0.5 to $2 \mathrm{~m}$ and comprises at least $70 \%$ of the benthic biomass in parts of Tampa Bay (Bloom et al. 1972, Simon \& Dauer 1972). Moreover, due to the fine grain of the sediments at the study site, all sizes of post-metamorphic lancelets could be reliably sieved from the substratum.

Lancelets probably spend most or all of their larval life in the plankton (Stokes \& Holland 1995b) and then settle to the bottom at the end of metamorphosis. The specific purposes of the present study were to use frequent (often daily) sampling to determine: the interval of the year when larval settlement occurs; the tempo of larval settlement; and rates of growth and secondary production during the juvenile and adult stages of the life history. Furthermore, the comprehensive data set was used to compare the efficacy of several mathematical models for estimating growth parameters in populations sampled much less frequently.

\section{METHODS}

Study site and sample collection. Lancelets Branchiostoma floridae were collected from approximately 0.5 to $2 \mathrm{~m}$ (depending on tidal height) of water, about $50 \mathrm{~m}$ off the southern shore of the Courtney Campbell Causeway $\left(27^{\circ} 50^{\prime} \mathrm{N}, 82^{\circ} 37^{\prime} \mathrm{W}\right)$, Old Tampa Bay, Florida, USA (Fig. 1, arrow). The study site was on transect 2 as illustrated in Bloom et al. (1972). Lancelets were collected daily during the summer months in August 1992, July through August 1993, and July through August 1994; samples were also collected sporadically from September 1992 through June 1993 and at least monthly from September 1993 through June 1994 (see Fig. 3A). All collections were made within a few meters of each other by visually triangulating off landmarks on shore. A summary description of the Tampa Bay estuarine system can be found in Simon (1974).

The lancelets were collected by sieving approximately $15 \mathrm{l}$ of sand by shovel through a $330 \mu \mathrm{m}$ mesh screen. The sediment at the collection site was so fine that most of the sand grains passed easily through the sieve when rinsed with bay water, and the lancelets were retained on the mesh. The sample was then preserved in $95 \%$ ethanol and individual lancelets measured to the nearest millimeter (from the tip of the rostrum to the tip of the caudal fin) in the laboratory. The effectiveness of the screen for retaining newly settled (4 to $5 \mathrm{~mm}$ ) lancelets was tested by fixing several unsieved sand samples in ethanol and repeatedly stir-

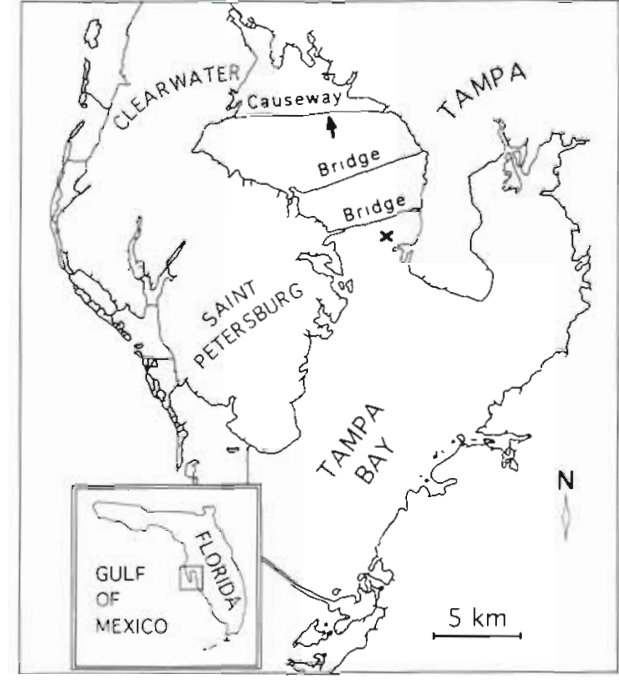

Fig. 1. Location of study area $\left(27^{\circ} 50^{\prime} \mathrm{N}, 82^{\circ} 37^{\prime} \mathrm{W}\right)$ in Old Tampa Bay, Florida, USA. Collecting site (arrow) is adjacent to the Courtney Campbell Causeway. Location of the PORTS $A D C P$ instrument for temperature measurement is indicated by $\times$. Inset map shows the location of Tampa Bay along the Gulf Coast of Florida, USA

ring them while collecting the lancelets floating in the supernatant.

Water temperature. Water temperature information was obtained from the Physical Oceanographic RealTime System (PORTS) station within Old Tampa Bay. This system provides water temperature and current speed/direction from an acoustic doppler current profiler (ADCP) installed in $8 \mathrm{~m}$ of water near Old Port Tampa (Fig. 1, at $\mathrm{x}$ ). The PORTS station is $7 \mathrm{~km}$ southsoutheast of the collection site and is maintained by the Greater Tampa Bay Marine Advisory Council in agreement with the National Ocean Service and NOAA's Global Ocean Observing System. The PORTS data are sampled in 6 min intervals, but for our purposes, it was convenient to average data for every 9 samples (= $54 \mathrm{~min}$ ) from June 1992 through September 1994. To test the correspondence between tempertures at the PORTS site and those at the study site, additional water temperature measurements were made at the latter location with a thermometer (HoboTemp ${ }^{\mathrm{TM}}$, Onset Instruments, Pocasset, Massachusetts, USA) recording temperatures every $6 \mathrm{~min}$ in $0.2^{\circ} \mathrm{C}$ increments (Fig. 2).

Growth. For each collection, lancelet lengths were divided into $1 \mathrm{~mm}$ size classes and length-frequency histograms were constructed. The modal length of different settling cohorts was plotted separately in order to follow their growth over the sampling period. Growth was quantitatively described using both monotonic growth functions (allowing direct applica- 
Fig. 2. Comparison of temperature fluctuations from the PORTS ADCP (location in Fig. 1) and recording thermometer at the study site (HoboTemp ${ }^{\mathrm{M}}$, Onset Instruments) from 20 to 23 July 1993. Grey bars indicate the period from sunset to sunrise. Square profile of the study site temperature record is due to the $0.2^{\circ} \mathrm{C}$ resolution of the recording thermometer

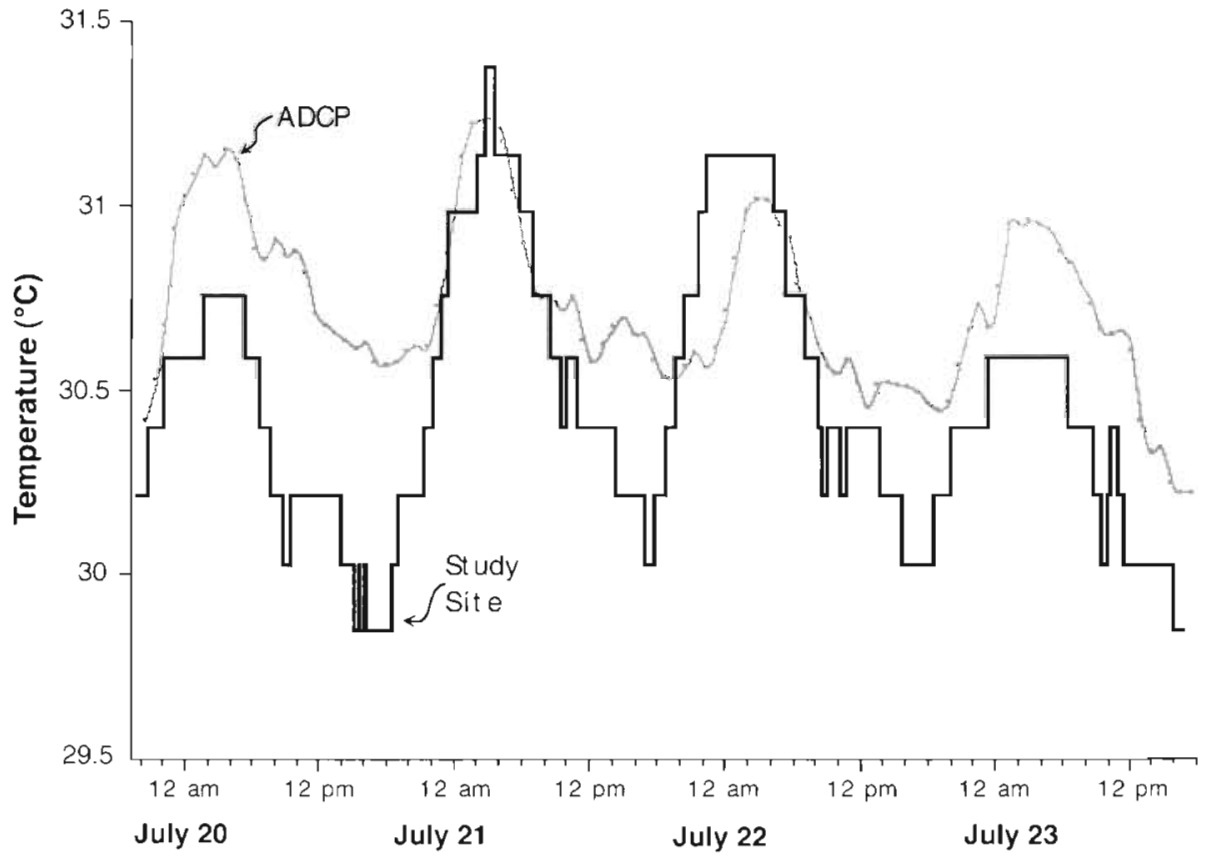

tion to calculations of secondary production) and seasonally oscillating functions. The data were analyzed in 2 different organizational formats as defined by Kaufmann (1981): first, as a cross-sectional data set recording cohort growth increments over $12 \mathrm{~d}$ periods of different individuals of different cohorts, all simultaneously, during the summer months of July and August and, second, as a longitudinal data set recording the increase in size of a cohort or cohorts collected sequentially in time throughout the year. The first method allowed a comparison of summer growth rates due to environmental differences because it effectively 'averaged' the growth of different sized individuals under similar conditions, while the second illustrated differences in growth rate throughout the seasons.

The following simple growth models were used in their integrated form to describe summer growth from the cross-sectional data sets:

\section{Power:}

$$
L(t)=b t^{a}
$$

Johnson's (Ricker 1979):

$$
L(t)=L_{(\max )} e^{-1 / k i}
$$

Gompertz (from Kaufman 1981):

$$
L(t)=L_{(\max )} \mathrm{e}^{-b \mathrm{e}^{-k t}}
$$

von Bertalanffy (von Bertalanffy 1938):

$$
L(t)=L_{(\max )}\left(1-b \mathrm{e}^{-k t}\right)
$$

$L(t)$ refers to body length at time $t$ in days from initial settlement; $L_{(\max )}$ is the maximum length or asymptotic length; $a(a<1.0)$ and $b$ are scaling factors and $k$ is the instantaneous growth rate coefficient.

In order to easily compare the parameter $k$ over different summers, the differential form of Eq. (4) was used (Kaufman 1981):

$$
G=k \frac{1}{L}-b
$$

where $G=\frac{1}{L} \frac{d L}{d t}$ is the length-specific growth rate.

Calculated in this manner and plotted as a change in length versus specific growth rate on a modified Ford-Walford plot (Ricker 1979, Kaufmann 1981), the slope $k$ can be estimated as a linear regression. This allows the easy comparison of slopes between years using the Student's $t$ statistic (Sokal \& Rohlf 1981).

As a means of incorporating possible seasonal influences on cohort growth, modified von Bertalanfy growth models incorporating an oscillating math function were applied to a longitudinal data set from July 1993 to September 1994. The modified functions and additional parameters were:

Cloern \& Nichols (1978):

$$
L(t)=L_{(\max )}\left(1-\mathrm{e}^{\left\{-a\left(t-t_{0}\right)-\frac{180 a}{\pi}\left[\cos \left(\frac{\pi\left(t_{0}+\theta\right)}{180}\right)-\cos \left(\frac{\pi(t+\theta)}{180}\right)\right]\right\}}\right.
$$

where $t_{0}$ is the time at settlement and parameters $a$ and $\theta$ determine the amplitude and period length of the oscillation, respectively, and: 
Sager \& Gosselck (1986):

$L(t)=$

$L_{(\max )}\left(1-e^{-k t}\right)\left\{1+\frac{(1-\varepsilon) k}{2 \pi(1-\beta)} \sin 2 \pi\left[t-t_{\alpha}-\frac{\beta}{2 \pi} \sin \left(2 \pi\left(t-t_{\alpha}\right)\right]\right\}\right.$

where $k$ is the growth constant, and the parameters $\beta$ and $\varepsilon$ jointly affect the form of oscillation, and

Clasing et al. (1994):

$L(t)=L_{(\max )}\left(1-\mathrm{e}^{|-k t|\left(t-t_{0}\right)+\left[C \sin \left(2 \pi\left(t-t_{s}\right) \mid 1 / 2 \pi\right)-\left\{C \sin \left(2 \pi t_{0}-t_{s}\right) \mid / 2 \pi \|\right)\right.}\right)$

where $k$ is the instantaneous growth constant, $t_{0}$ is the age at which length is effectively zero, $t_{\mathrm{s}}$ is the starting point of the oscillation and $C$ affects the oscillation amplitude.

These models incorporate either a direct replacement of the parameter $k$ with an oscillating function, as in Eq. (6), or involve multiplying a simple von Bertalanffy growth model, Eq. (4), by an oscillating function as in Eqs. (7) \& (8) to simulate the effects of a simple seasonal cycle on cohort growth.

Calculation of secondary production. A sample of 44 live individuals of Branchiostoma floridae was blotted dry with paper toweling, and each lancelet was weighed to provide a wet (damp) weight, measured to the nearest $\mathrm{mm}$, and then dried in a vacuum desiccator over sulfuric acid for $12 \mathrm{~h}$ to provide a dry weight measurement. Ash-free dry weights were measured to the nearest $10 \mu \mathrm{m}$ after combustion for $4 \mathrm{~h}$ at $500^{\circ} \mathrm{C}$ in a muffle furnace. Length/mass relations were then determined for ash-free dry weight (AFDW), dry weight (DW) and wet weight (WW).

Two different methods of calculating secondary production were used and estimates made for maximum and minimum observed population densities. The first method yielded secondary production utilizing the mass-specific growth rate (see method 3A, Crisp 1984) and was based on an average length-frequency sample produced from pooled samples, the parameters of the monotonic von Bertalanffy growth function, and the calculated length/mass relation.

$$
P=\sum\left(N_{2} M_{1} S_{i} \Delta t\right)
$$

The production $P$ is calculated as the sum over $i$ size classes of: $N_{1}$, the number of animals (number $\mathrm{m}^{-2}$ ) in class $i_{i} M_{1}$, the average individual body mass (AFDW) in size class $i_{i} \Delta t$, the sampling period ${ }_{i}$ and $S_{11}$ the massspecific growth rate, and is calculated as:

$$
S_{1}=b k\left(\frac{L_{\operatorname{maxi}}}{L_{1}}-1\right)
$$

The parameters of Eq. (10) are calculated from Eq. (4) and $L_{1}$ is the mean length of size class $i$.

The second method yielded secondary production by the average cohort method (see discussion in Vetter
1995). Loss in biomass between successive size classes was calculated from an average cohort based on the pooled length-frequency samples. The basic Hynes \& Coleman production equation has been modified by Hamilton (1969) and Benke (1979) and is used here:

$$
P=\left\{i \sum_{j=i}^{i}\left[\left(\bar{N}_{j}-\bar{N}_{j+1}\right)\left(, \bar{W}_{j} W_{j+1}\right)\right]\right\} \frac{365}{\mathrm{CPI}}
$$

where $P$ is the estimated average production, $i$ is the number of size classes, $N$, is the number of individuals in size class $j, W$, is the average AFDW of individuals in size class $j$ and CPI is the cohort production interval estimated from the length of time to reach sexual maturity (Benke 1979).

Data analysis. All growth equations and length/mass relations were analyzed using an iterative, non-linear. least-squares regression model (the Levenberg-Marquardt method; Press et al. 1988) on a Macintosh ${ }^{\text {TM }}$ computer and, where required, using parameters initially seeded from approximations in the literature (Cloern \& Nichols 1978, Sager \& Gosselck 1986, Clasing et al. 1994). Other statistics were computed using the Systat program (Systat 1992) and Sokal \& Rohlf (1981).

\section{RESULTS}

The Florida lancelet Brancinostoma floridae was the most abundant macrofaunal species living in the sediment at the study site (Fig. 1, arrow) throughout the present study. The substratum was predominantly fine quartz sand (average grain diameter about $200 \mathrm{\mu m}$ ). This lancelet-rich habitat extended for about $0.5 \mathrm{~km}$ to the west and $2 \mathrm{~km}$ to the east of the study site.

During this period (August 1992 through September 1994), salinities (as determined by refractometer) ranged from 23 to $29 \%$. Water temperatures, which are a key determinant of growth rate, were recorded by the PORTS ADCP sensor. This sensor, although located $(X$ in Fig 1) at $8 \mathrm{~m}$ depth about $7 \mathrm{~km}$ south-southwest of the study site (arrow in Fig. 1), recorded temperatures that matched reasonably well with those in the habitat of the lancelets (Fig. 2) Because of the shallowness of the study site (about $1.5 \mathrm{~m}$ at mid tide), air temperature had a stronger influence on water temperatures there. The latter could become almost a half degree warmer in late afternoon (with a maximum at about 14:00 to 15:00 h) and about a degree cooler in the early hours of the morning (with a minimum at about 02:00 to 03:00 h) in comparison to the PORTS data (Fig. 2). Water temperatures fluctuated from $15^{\circ} \mathrm{C}$ in winter (December through March) to $33^{\circ} \mathrm{C}$ in summer 
(May through September) (see Fig. 5B). Also of note was a period of extremely warm weather without daily afternoon thunder showers during mid July 1993, and a cool period during late August 1994 associated with the passing of tropical storm Berril.

\section{Settlement and growth}

Lancelets were sieved from the substratum on the dates summarized in Fig. 3A. For the study as a whole, 54264 lancelets were measured ranging from a minimum of $4 \mathrm{~mm}$ long to a single individual that was
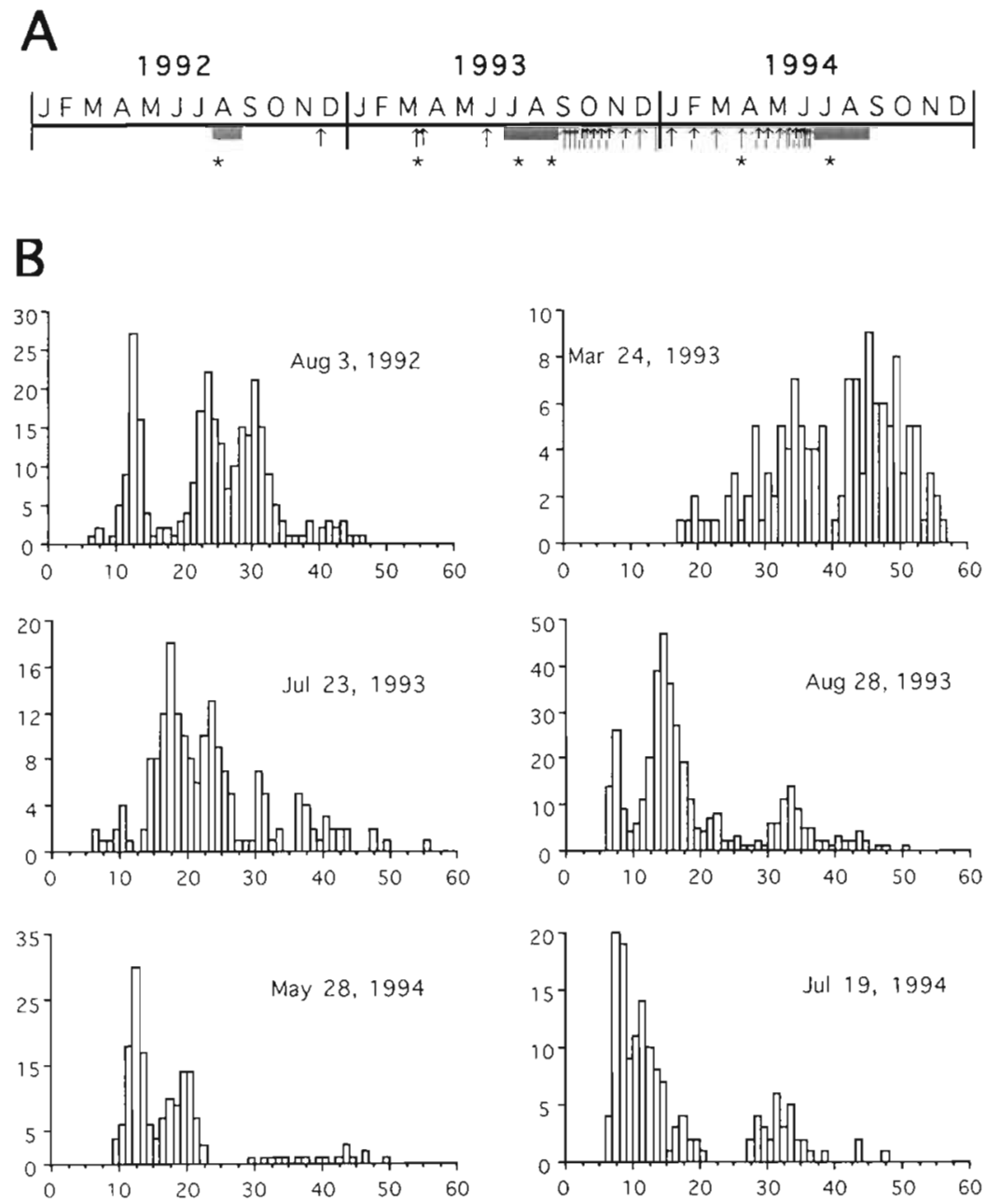

Length $(\mathrm{mm})$

Fig. 3. Branchiostoma floridae. (A.) Graphic summary of sampling regime. Grey bars indicate periods of continuous daily sampling; $(\uparrow)$ discontinuous samples; (") dates of selected histograms shown in (B) selected length-frequency histograms during the sampling period. Histograms show a variety of different profiles, some ( 3 August 1992) with more distinct cohorts than others. Note the change in frequency scale between histograms
$58 \mathrm{~mm}$ long. The smallest individuals corresponded to the size at the end of metamorphosis (Stokes \& Holland 1995a). It seems likely that most, if not all, of the recently settled lancelets were retained by the collecting sieve because similar results were obtained with whole sediment samples. Lengths of the animals were plotted as length-frequency histograms. Due to spatial Fig. $3 B$, the histogram shapes varied considerably throughout the year. Individual cohorts were most distinct in summer after periods of settlement, with 6 to 8 cohorts often identifiable (e.g. Fig. 3B, 23 July 1993).

In Fig. 4, the growth of a settled cohort about $14 \mathrm{~mm}$ long (modal length indicated by the arrowhead) is followed in $3 \mathrm{~d}$ increments from 18 to 30 July 1993. During this period, the cohort increased in length from about 14 to about $20 \mathrm{~mm}$ and the settlement of a new 5 to $6 \mathrm{~mm}$ cohort could be seen on 27 July (double arrowhead), which grew to about $7 \mathrm{~mm}$ by 30 July. It should be noted that plotted on this frequency scale, older cohorts $>30 \mathrm{~mm}$ in length are less distinct; however, they are identifiable when the scale is expanded (data not shown).

Fig. 5 shows post-settlement changes in cohort modal body length from length-frequency histograms sampled during the study. Multiple settlements commenced in May and continued through October with new settlements at intervals of approximately every 1 to $3 \mathrm{wk}$. Growth of all cohorts was rapid in summer 1992, but sampling during winter 1992 to 1993 was too infrequent to permit cohort growth to be followed unequivocally. In contrast, the much more complete data set from early summer 1993 through late summer 1994 clearly demonstrated the annual growth pattern. Growth was most rapid in summer (June through August) during periods of higher water temperature $\left(>25^{\circ} \mathrm{C}\right.$ ) and slowest (almost stagnant) November through February during periods of cooler water temperatures $\left(<25^{\circ} \mathrm{C}\right)$. It is also evident that growth is comparatively slower in older, larger individuals than in the smaller ones, regardless of time of year. 

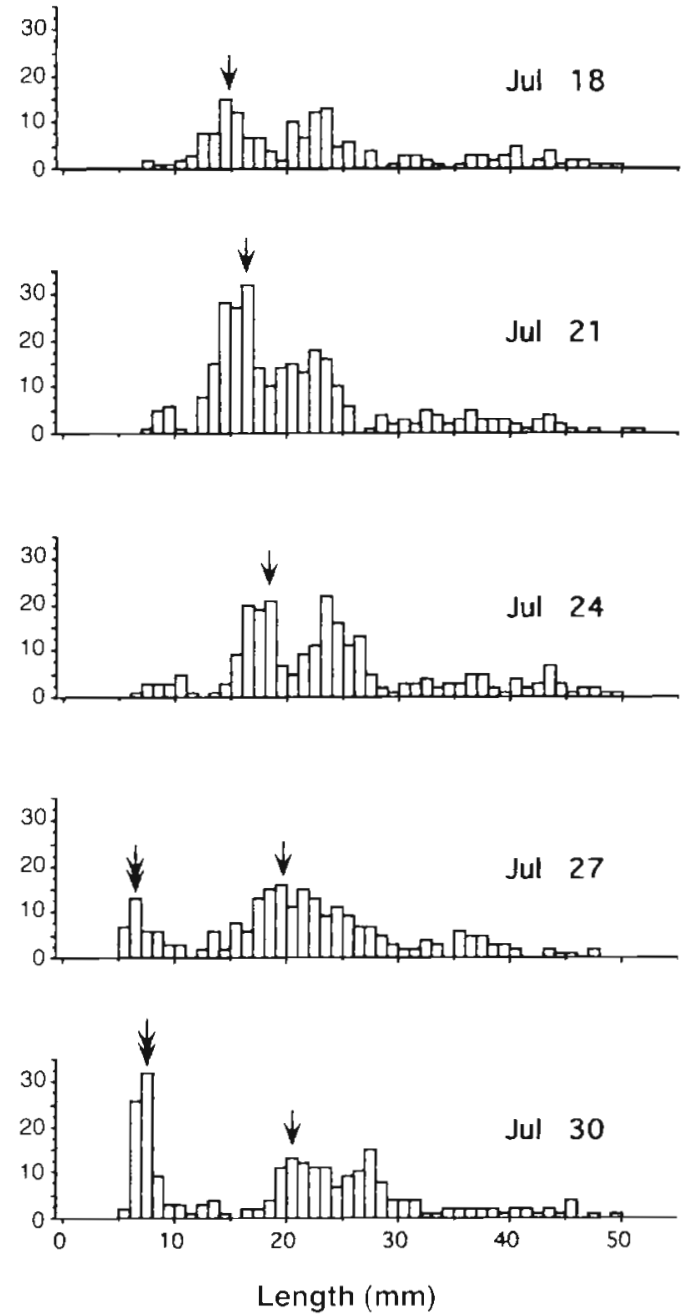

Fig. 4. Branchiostoma floridae. Size-frequency histograms at 3 d intervals from 18 through 30 July 1993. ( $\downarrow$ ) increase in cohort body length from about 14 to $20 \mathrm{~mm}$; settlement on 27 July and subsequent growth

\section{Growth models}

By reorganizing the daily modal data into $12 \mathrm{~d}$ crosssectional data sets for July and August 1992, 1993, and 1994 (Fig. 6), the decrease in growth rate with increasing age/body length is evident. Also, growth in summer 1993 appears slightly slower than in 1992 and 1994 Table 1 summarizes the results of non-linear regression analysis of various simple growth models (Eqs. 1 to 4 ) fit to the cross-sectional data $(152 \leq n \leq 341)$. In all calculations the parameter $L_{(\max )}$ was fixed at $58 \mathrm{~mm}$. The von Bertalanffy growth model, Eq. (4), produced the best fit, with an $R^{2}=0.986$ to 0.993 and values for the parameter $k$ of $0.0110,0.0069$ and 0.01 .05 for the summers of 1992 , 1993 and 1994. respectively. The other models gave fairly close fits to the data as well. The differential form of the von Bertalanfy growth function, Eq. (5), yielded estimates of the growth rate coefficient of $0.01,0.008$, 0.01 over the same summers. According to the Student's $t$ test $(p<0.001)$, the growth rate coefficient was significantly different in 1993 from that in other years.

Fig. 7 shows simple, monotonic growth models (with $L_{\text {(max) }}$ fixed at $58 \mathrm{~mm}$ ) fit to a longitudinal data set of a single cohort that settled in August 1993. These models fail to adequately describe growth when following a single cohort through time even though the regression coefficient of determination $\mathrm{R}^{2}$ was sometimes high $(0.910,0.788,0.921,0.892$ for the Power, Johnson's, Gompertz and von Bertalanffy growth models, respectively).

The incorporation of seasonally oscillating functions into the Bertalanffy model yielded much closer descriptions of lancelet growth throughout the year (Fig. 8, Table 2). No one oscillating model accurately fit all size phases of growth, but all showed rapid growth followed by a degree of stagnation in the cooler winter period. The Cloern \& Nichols (1978), Eq. (6), and Clasing et al. (1994), Eq. (8), models both underestimated later growth, while the Sager \& Gosselck (1986) model, Eq. (7), although providing the best fit, underestimated early growth. Also, Eq. (7) provided a better fit $\left(\mathrm{R}^{2}=\right.$ $0.990)$ when $L_{(\max )}$ was underestimated as $47 \mathrm{~mm}$, than when $L_{(\max )}$ was fixed at $58 \mathrm{~mm}\left(\mathrm{R}^{2}=0.975\right)$. Eqs. (6) \& (8) provided the best fit when overestimating $L_{(\max )}$ as $64 \mathrm{~mm}$ (Table 2).

From the nonlinear regressions, the best fitting estimates for the parameters of each model were: Eq. (6), Cloern \& Nichols (1978), $a=2.677 \times 10^{-3}, \theta=-99.34$ $t_{0}=2.401 \times 10^{2} ;$ Eq. (7), Sager \& Gosselck (1986), $k=$ 1.217, $\beta=-50.016, \varepsilon=1.258 \times 10^{-8} ; \mathrm{Eq}$. (8), Clasing et al. (1994), $k=1.245, t_{0}=-3.051 \times 10^{-2}, t_{\mathrm{s}}=8.677 \times 10^{-3}$, $C=1.328$.

The Cloern \& Nichols (1978) model and the aforementioned parameters were used to estimate the growth of simulated settlements from May through September over 2 yr (Fig. 9). The simulation portrays rapid cohort growth during the warm summer months, with slower, stagnating growth during the cooler months, very similar to Fig. 5.

\section{Length/mass}

The lancelet length/mass relations, as shown in Fig. 10, were calculated to be [with $L=$ body length $(\mathrm{mm})$ and $W t=$ body mass $(g)]: W t_{\text {wet }}=2.357 \times 10^{-6} \times L^{2.895}\left(\mathrm{R}^{2}=\right.$ $0.99, \mathrm{n}=44) ; W t_{\mathrm{dry}}=4.934 \times 10^{-7} \times L^{2.927}\left(\mathrm{R}^{2}=0.99, \mathrm{n}=\right.$ 44); $W i_{\text {ash free }}=5.611 \times 10^{-7} \times L^{2.868}\left(\mathrm{R}^{2}=0.99, \mathrm{n}=44\right)$.

The percentage of body mass comprised of ash was very small. The mean percentage of ash was $6.36 \%$ $(\mathrm{SD}=3.25 \%, \mathrm{n}=44)$ and the mean percentage of water was $76.63 \%(\mathrm{SD}=2.76, \mathrm{n}=44)$ 
Fig. 5. Branchiostoma floridae (A) Change in modal length (derived from length-frequency histograms) of cohorts from July 1992 through September 1994. (B) PORTS, ADCP temperature record from July 1992 through September 1994. Gaps in temperature record are due to missing records in the PORTS data

Fig. 6. Branchiostoma floridae. Cohort body length versus days since settling. Cross-sectional data set was generated from $12 \mathrm{~d}$ intervals during July 1992 (4), and through July and August 1993 (D) and 1994 (O)
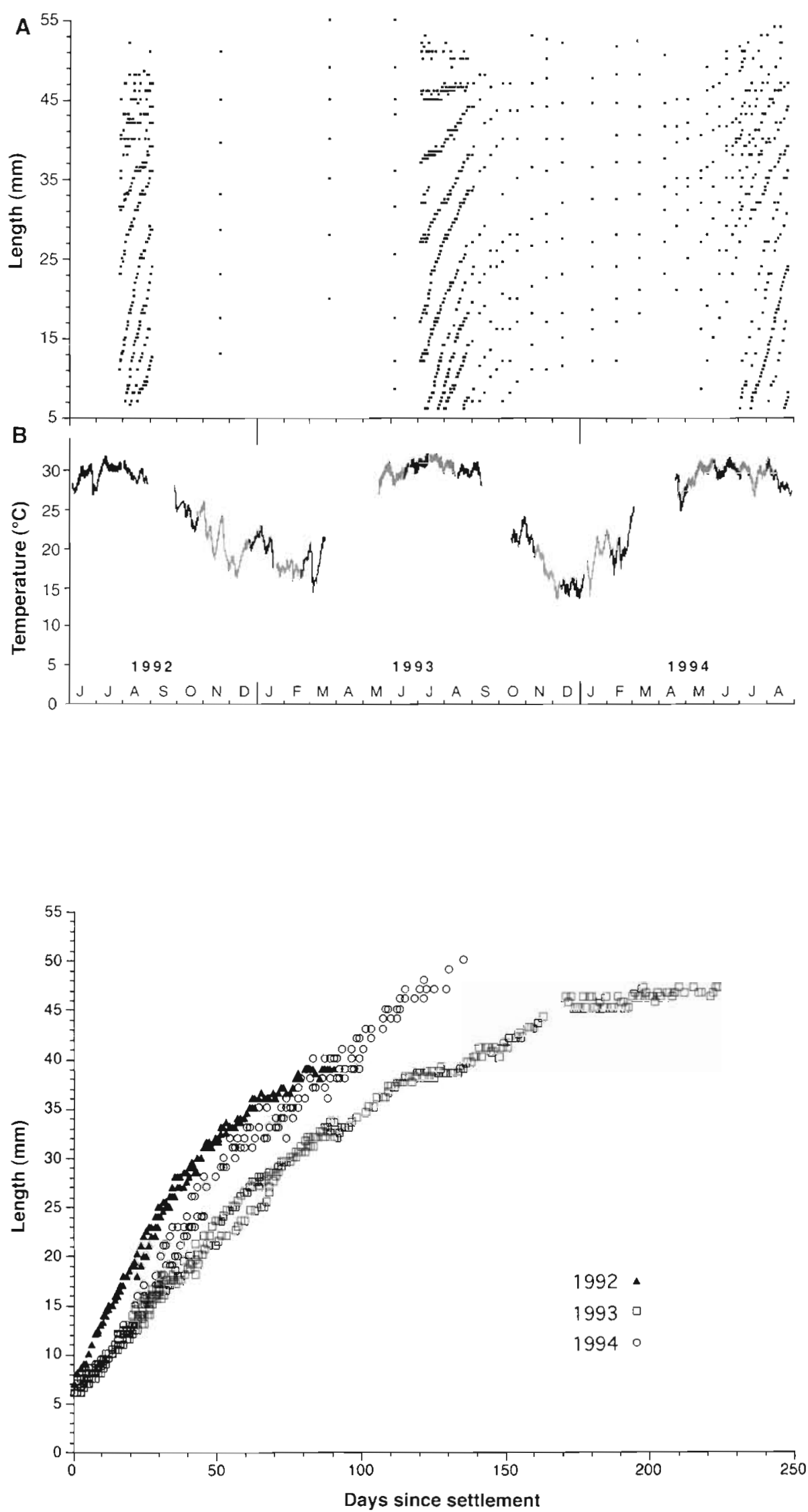
Table 1. Branchiostoma floridae. Comparison of non-linear regression analysis of simple growth models fitted to the crosssectional data sets shown in Fig. 6. Descriptions of the models can be found in the text. $R^{2}$ is the coefficient of determination derived from the regression, $k$ is the growth rate coefficient and $b$ is a scaling factor not necessarily comparable among models. In all cases $L_{(\max )}$ was fixed at $58 \mathrm{~mm}$

\begin{tabular}{|c|c|c|c|c|c|c|c|c|c|c|c|c|c|}
\hline \multirow[t]{2}{*}{ Year } & \multirow[b]{2}{*}{$n$} & \multicolumn{3}{|c|}{ Power } & \multicolumn{3}{|c|}{ Johnson's } & \multicolumn{3}{|c|}{ Gompertz } & \multicolumn{3}{|c|}{ von Bertalanffy } \\
\hline & & $b$ & $a$ & $\mathrm{R}^{2}$ & $b$ & k & $\mathrm{R}^{2}$ & $b$ & k & $\mathrm{R}^{2}$ & $b$ & k & $\mathrm{R}^{2}$ \\
\hline 1992 & 152 & 4.452 & 0.4922 & 0.976 & 0.743 & 0.0444 & 0.973 & 2.064 & 0.0185 & 0.947 & 0.950 & 0.0110 & 0.986 \\
\hline 1993 & 341 & 2.960 & 0.5198 & 0.957 & 0.876 & 0.0198 & 0.980 & 2.319 & 0.0116 & 0.957 & 0.991 & 0.0069 & 0.993 \\
\hline 1994 & 189 & 2.688 & 0.5857 & 0.957 & 0.990 & 0.0226 & 0.981 & 2.632 & 0.0186 & 0.973 & 1.034 & 0.0105 & 0.988 \\
\hline
\end{tabular}

\section{Secondary production}

From the mass-specific growth rate method of calculating secondary production (Eqs. 9 \& 10), the parameters of the above length/mass relations and the parameters of the von Bertalanffy growth model, production was calculated to be $5.35 \mathrm{~g} \mathrm{~m}^{-2} \mathrm{yr}^{-1}$ AFDW, $5.78 \mathrm{~g} \mathrm{~m}^{-2} \mathrm{yr}^{-1} \mathrm{DW}$ for the minimum lancelet population density observed (100 ind. $\mathrm{m}^{-2}$ ), and $61.53 \mathrm{~g} \mathrm{~m}^{-2} \mathrm{yr}^{-1}$ AFDW, $66.48 \mathrm{~g} \mathrm{~m}^{-2} \mathrm{yr}^{-1} \mathrm{DW}$ for the maximum lancelet population density observed (1200 ind. $\mathrm{m}^{-2}$ ). The production to biomass ratio (P:B) was 11.64

From the average cohort method (Eq. 11), and a CPI of $50 \mathrm{~d}$ (Benke 1979, unpubl. data) production was calculated to be $3.88 \mathrm{~g} \mathrm{~m}^{-2} \mathrm{yr}^{-1}$ AFDW, $4.24 \mathrm{~g} \mathrm{~m}^{-2} \mathrm{yr}^{-1} \mathrm{DW}$
Table 2. Branchiostoma floridae. A comparison of coefficients derived from the non-linear regression analysis of the seasonally oscillating growth models, fitted to a longitudinal data set (see Fig. 8). Descriptions of the models can be found in the text. $k$ is the growth rate coefficient, $R^{2}$ is the coefficient of determination derived from the regression and shown for analysis including the best fit $L_{(\max )}$ and for $L_{\text {(max) }}$ fixed at $58 \mathrm{~mm}$

\begin{tabular}{|lccc|}
\hline Growth model & \multirow{3}{*}{$k$} & $L_{\text {(mix) }}(\mathrm{mm})$ & $\mathrm{R}^{2}$ \\
\hline Cloern \& Nichols (1978) & - & 64 & 0.977 \\
& & 58 & 0.974 \\
Sager \& Gosselck (1986) & 1.217 & 47 & 0.990 \\
& & 58 & 0.975 \\
Clasing et al. (1994) & \multirow{2}{*}{1.245} & 64 & 0.983 \\
& & 58 & 0.977 \\
\hline
\end{tabular}

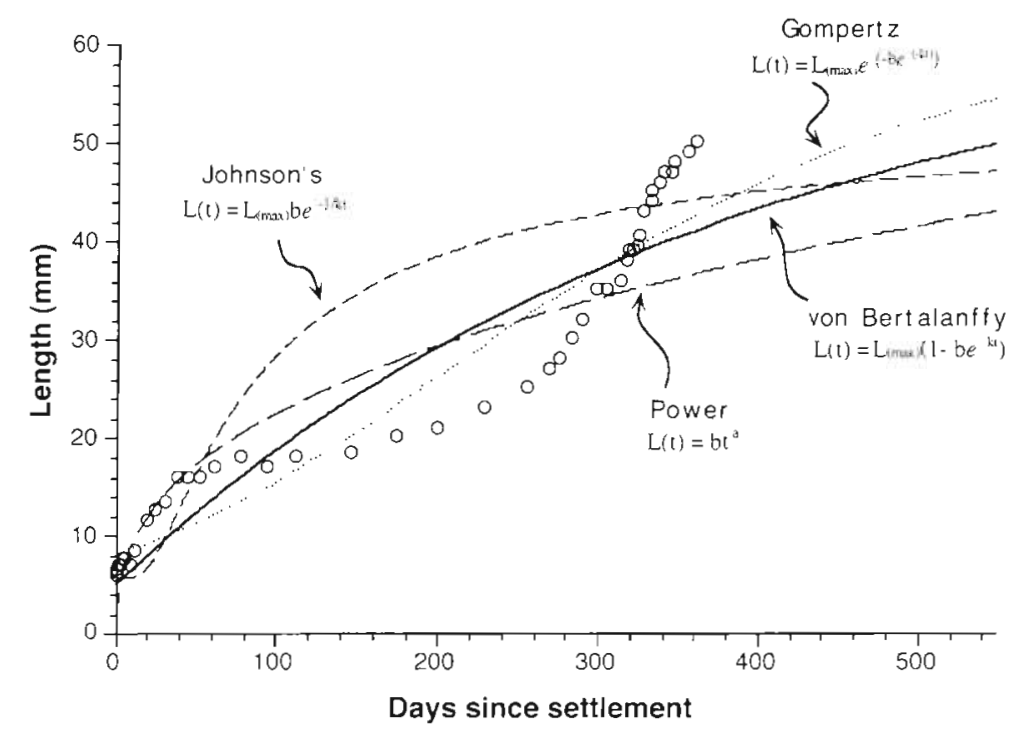

Fig. 7. Branchiostoma floridae. Comparison of simple growth models fitted to a longitudinal data set from 1 cohort. Descriptions of the models can be found in the text. In all cases $L_{\text {max }}$ was fixed at $58 \mathrm{~mm}$. As labeled, the

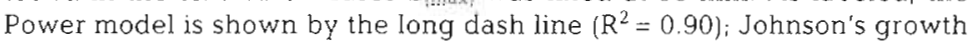
model by the short dash line $\left(\mathrm{R}^{2}=0.78\right)$; Gompertz growth model by the dotted line $\left(R^{2}=0.91\right)$; and the von Bertalanfy model by the solid line $\left(\mathrm{R}^{2}=0.89\right)$ for the minimum lancelet population density, and $44.63 \mathrm{~g} \mathrm{~m}^{-2} \mathrm{yr}^{-1}$ AFDW, $48.75 \mathrm{~g}$ $\mathrm{m}^{-2} \mathrm{yr}^{-1} \mathrm{DW}$ for the maximum lancelet population density observed. The P:B was 7.91 .

\section{DISCUSSION}

The study of growth of Branchiostoma floridae in OId Tampa Bay was facilitated by a combination of favorable circumstances. The population was enormous and was evidently not appreciably affected by the removal of daily samples; growth rates were high; and the population could easily be divided into separate cohorts, each traceable from a discrete larval settlement. Thus cohorts were recognized without recourse to graphical methods (Harding 1949) or computation-intensive statistical methods (MacDonald \& Pitcher 1979, Fournier et al. 1990)

The cohort modal lengths derived from the sample length-frequency histograms were fit to model growth functions in 2 dif- 


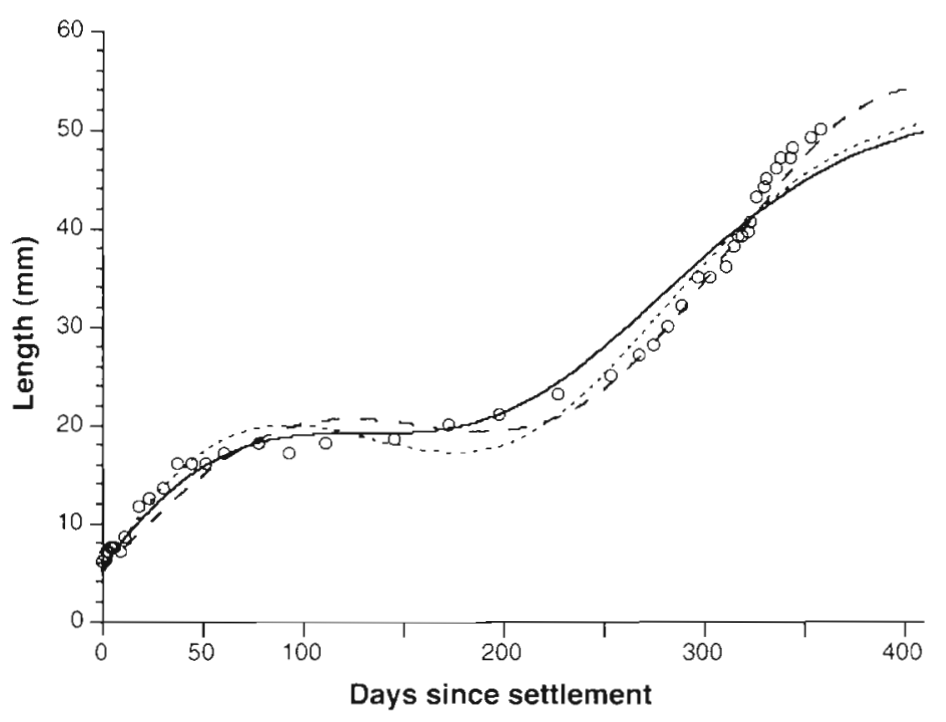

Fig. 8. Branchiostoma floridae. Comparison of seasonally oscillating growth models (modified von Bertalanffy growth functions) fitted to a longitudinal data set from one cohort. Descriptions of the models can be found in the text. Solid line represents the Cloern \& Nichols (1978) model, Eq. $(6),\left(R^{2}=0.977\right)$; dashed line shows the Sager \& Gosselck (1986) model, Eq. (7), ( $\left.\mathrm{R}^{2}=0.990\right)$ and dotted line shows the Clasing et al. (1994) model, Eq. (8), $\left(R^{2}=0.983\right)$

ferent formats, the first cross-sectional and the second longitudinal. Organizing the growth record as a crosssectional data set - similar to a 'mark and recapture' data set (Kaufmann 1981) - over a short period of time assumes that all the lancelets, regardless of age, are following the same growth trajectory. By exploiting this assumption, which may not be necessarily always true, particularly among different years and/or populations, it is possible to examine the average intrinsic growth responses of the organism which are tangled with those generated due to extrinsic, environmental sources. Organizing the samples as a longitudinal data set, in which a record of the change in size of an individual cohort is followed sequentially in time, illustrates growth in the continously fluctuating environment. If environmental conditions were constant over the entire interval of sampling, then the growth curves generated from the longitudinal data and from the cross-sectional data would be congruent.

Although all the simple models tested provided reasonable fits to the summer cross-sectional data as indicated by their high $\mathrm{R}^{2}$ (Table 1 ), not all are reasonable choices for approximating lancelet growth during the juvenile and adult stages. The Power curve assumes indeterminate growth with no upper boundary, while the other models assume that growth declines until a maximum size is approached asymtotically. The Gompertz and Johnson's growth curves are sigmoid and therefore express postsettlement lancelet growth less accurately than the von Bertalanffy function. The values of the parameter $k$, the instantaneous growth rate coefficient, calculated by these methods cannot be statistically compared among different models, but can, as in the case of Eq. (5), be compared among different years. The von Bertalanffy function (Eq. 4) has already been shown to describe growth more accurately than 3 -and 4-parameter polynomial functions in 6 species of freshwater fish (Chen et al. 1992) and has proven to be a useful model in many other studies of marine vertebrates (e.g Ricker 1979, Fournier et al. 1990) and invertebrates (e.g. Brey et al. 1990, Roa 1993, Clasing et al. 1994, Lumingas \& Guillou 1994) where growth rate declines with age/size. In the present study, the simple von Bertalanffy growth model described cross-sectional, post-metamorphic growth better than the other non-linear functions tested. However, application of this model and/or the model para-

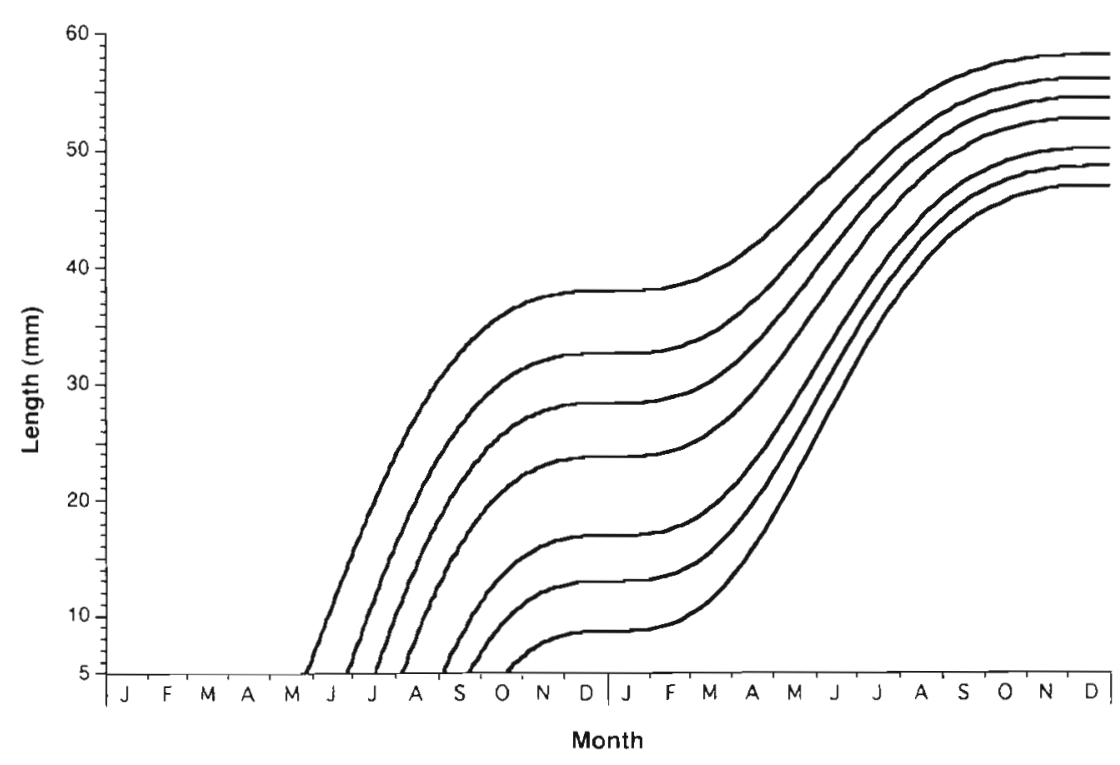

Fig. 9. Branchiostoma floridae. Predicted post-settlement body length over a 2 yr period, calculated from the Cloern \& Nichols (1978) model, Eq. (6), using the following coefficients: best fit $L_{(\max )}=64 \mathrm{~mm}, a=2.677 \times 10^{-3}, \theta=-99.349$. Complete model description can be found in the text 


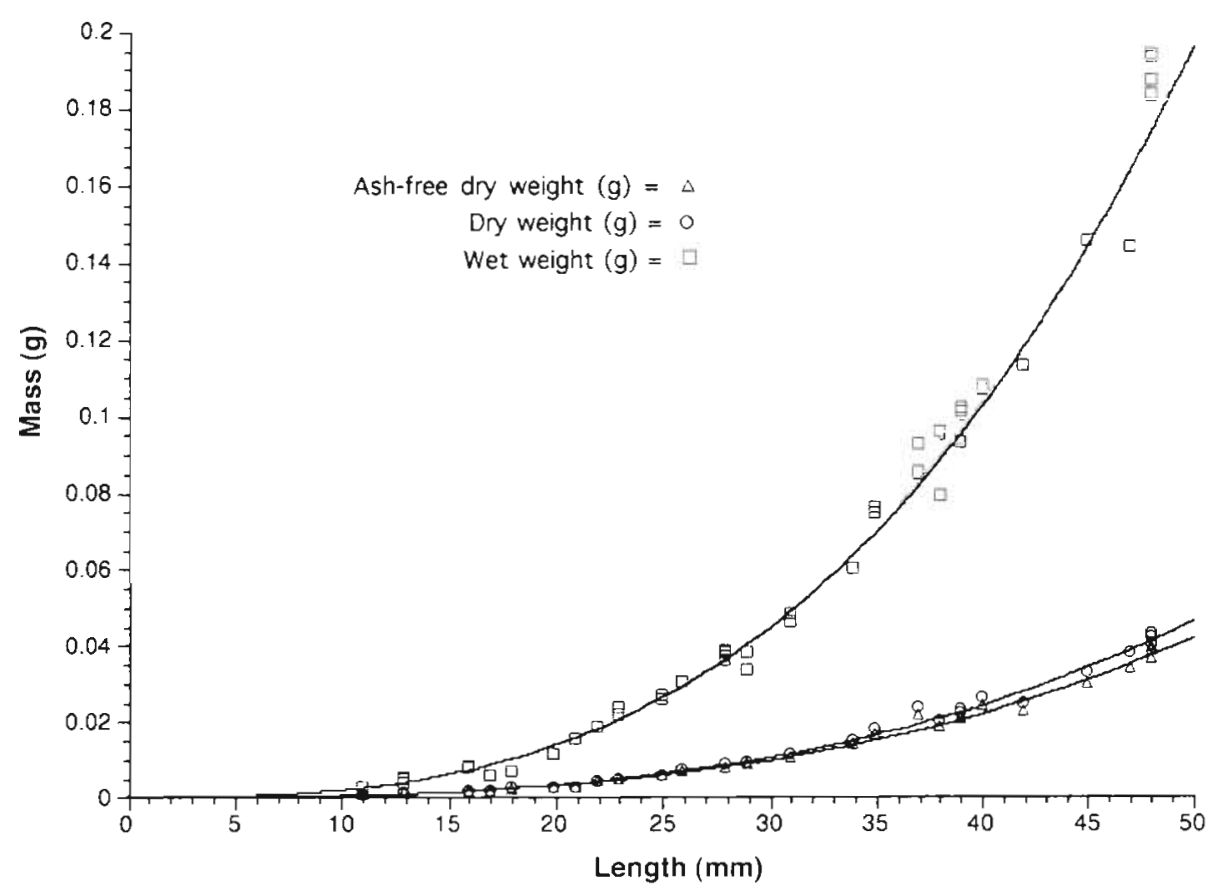

Fig. 10. Branchiostoma floridae. Length/mass relations for post-settlement lancelets $(\mathrm{n}=44)$. (口) wet weight (WW); (O) dry weight $(D W)_{i}(\Delta)$ ashfree dry weight (AFDW) meters to premetamorphic lancelet growth would have yielded results very different from 'true' growth during early ontogeny by grossly overestimating larval size (Stokes \& Holland 1995a).

Fitting growth functions to the cross-sectional data sets (Fig. 6) revealed the differences in growth among successive summers. Viewed in this manner, growth during summer was slightly slower in 1993 than in 1992 and 1994 as shown by the difference in the calculated growth coefficient $(k)$ for all the functions tested (Table 1). This difference was statistically significant for the von Bertalanffy model. During mid July 1993 there was a $10 \mathrm{~d}$ period of exceptionally high air temperatures and an abnormal absence of the thunder showers usual each afternoon. At this time, shallow water tempertures inshore from the study site were high enough to kill many small fishes (e.g. small gobies, juvenile spadefish) living in this habitat (Stokes pers. obs.) and may have had negative effects on the benthic lancelet community. Although the water temperature was not recorded at the study site during this episode, it was probably around the maximum $\left(36.9^{\circ} \mathrm{C}\right)$ ever recorded for Tampa Bay (Simon 1974). Similarly, a period of unseasonably cold weather associated with the edge of the slow moving tropical storm Berril during late August 1994 may have influenced lancelet growth, but the data set does not extend far enough into September 1994 to demonstrate an obvious effect.

The simple von Bertalanffy growth model rests on assumptions: at the time of settlement, the body size is at a minimum and is constant; at this minimum size the size-specific growth rate is maximum, but decreases linearly with body size; and there is a constant upper limit to growth. These assumptions may be reasonable to make for some populations and/or if the data have been arranged in a cross-sectional format. However, for Branchiostoma floridae, the growth rate does not decrease linearly with size and remains invariant in time, so the basic von Bertalanffy function has been modified to vary seasonally in a manner similar to water temperature.

Courtney (1975) described the growth of a population of the European lancelet Branchiostoma lanceolatum near Helgoland, Germany, in the North Sea. Growth decreased logarithmically with age; Courtney (1975) also mentioned that growth rates were low during winter months. Sager \& Gosselck (1985), in a reexamination of Courtney's (1975) data, obtained a much better fit, including the seasonal change, with a simple von Bertalanffy growth function yielding a $70 \%$ reduction in error. In a subsequent paper, Sager \& Gosselck (1986) included seasonally oscillating growth via a modification of the simple von Bertalanffy function (Eq. 7, present study) and could describe growth in $B$. lanceolatum including relative stagnation during cold winters. The seasonally oscillating $k$ was 0.2914 in the slow-growing Helgoland population.

In the present study, the oscillating model (Cloern \& Nichols 1978) that provided the least accurate fit to the sample data (Eq. 6, present study), still did an excellent job of describing the fluctuating growth rates and growth stagnation during the different seasons. The 
growth trajectories produced by this model clearly illustrate the 'catch-up' phenomenon whereby the smallest-sized cohorts at the end of one summer season catch up in length to the older, larger cohorts at the start of the next summer season due to their relatively faster growth rate.

For Branchiostoma floridae, the observed summer growth rate (of up to $0.5 \mathrm{~mm} \mathrm{~d}^{-1}$ for recently settled individuals) was much faster than the only other published growth rates for the same and other lancelet species. McShine (1971) studied a population of lancelet (that was probably $B$. floridae) in Kingston Harbor, Jamaica, and recorded post-settlement growth of greater than $2 \mathrm{~mm} \mathrm{mo}^{-1}$ at a water temperature of 25 to $32^{\circ} \mathrm{C}$, although samples were only taken monthly and it was impossible to follow cohorts for more than 2 mo at a time. Webb (1958) reported post-settlement growth of 10 to $12 \mathrm{~mm} \mathrm{mo}^{-1}$ for $B$. nigeriense during March in Lagos Lagoon, Nigeria, corresponding to both warm water (about $30^{\circ} \mathrm{C}$ ) and increased nutrient flux into the lagoon during the start of the rainy season. Early post-settlement growth of $B$. senegalense was about $22 \mathrm{~mm} \mathrm{yr}^{-1}$ (Gosselck \& Spittler 1979), decreasing logarithmically with age, at a relatively constant temperature of approximately $16^{\circ} \mathrm{C}$ off northwest Africa. Chin (1941) and Wu et al. (1994) reported early juvenile growth rates of about 2.5 to $3 \mathrm{~mm} \mathrm{mo}^{-1}$ for $B$. belcheri in Xiamen (Amoy) and Qingdao, China, during summer $\left(25\right.$ to $\left.30^{\circ} \mathrm{C}\right)$ and about $1 \mathrm{~mm} \mathrm{mo}^{-1}$ during winter $\left(<20^{\circ} \mathrm{C}\right)$. In a study of the age structure of $B$. lanceolatum in the North Sea off Helgoland $\left(0\right.$ to $17^{\circ} \mathrm{C}$ yearly temperature range) and in the warmer water at Le Racou on the French Mediterranean coast (10 to $24^{\circ} \mathrm{C}$ yearly temperature range), Courtney (1975) reported initial growth rates of 10 and $20 \mathrm{~mm} \mathrm{yr}^{-1}$, respectively, with growth fastest during the warmest months of the year and a logarithmic decrease in growth with age.

Examination of Fig. 5 indicates that maximum body length can likely be attained in 2 seasons, but the present results do not provide the maximum age for Branchiostoma floridae. In a study of this very same lancelet population, Nelson (1969) claimed 3 year classes were present but mistakenly attributed each cohort to settlement in a separate year. Since his study only sampled the population monthly, multiple settlements during summer were missed, and, because a $1 \mathrm{~mm}$ sieve was used for collection, no individuals less than $10 \mathrm{~mm}$ in length were ever sampled. Despite this, $3 \mathrm{yr}$ is probably a reasonable estimate for the maximum age of $B$. floridae and corresponds with most other estimates of lancelet maximum age. The studies of Wells (1926) and Futch \& Dwinell (1977) both suggested a 2 to 3 yr lifespan for $B$. floridae based on the apparent number of generations present in the sampled size-frequency his- tograms. Chin (1941) suggests a maximum age of 2 to 3 yr for $B$. belcheri. A considerably longer lifespan of 8 yr was suggested by Courtney (1975) and Gosselck \& Spittler (1979) for $B$. lanceolatum living in the relatively cold waters off Helgoland.

For the Tampa population of Branchiostoma floridae, the fluctuation in water temperature throughout the year is probably the dominant factor causing the seasonal variation in growth rate and population structure, although this is not the only environmental factor that could do so. Variations in nutrient supply could also affect lancelet growth as seen in other invertebrates (e.g. Sprung 1995). Chlorophyll a concentrations in Tampa Bay range from moderate levels of 2 to $5 \mathrm{\mu g} \mathrm{l}^{-1}$ in winter to very high values of 12 to $16 \mathrm{\mu g} \mathrm{l}^{-1}$ in summer (Jiang \& Paul 1994). The available food supply in Tampa Bay is most likely not limiting during winter because food reserves (in the form of the inappropriately named fin rays) are prominant all winter. Lancelet fin rays are actually retroperitoneal accumulations of haemal fluid (rich in lipids, proteins, and carbohydrates) that project into the fin-box coeloms (Azariah 1965, Holland \& Holland 1991). When lancelets are starved for several weeks in the laboratory their fin rays shrink and disappear (Stokes pers. obs.).

Tampa Bay receives large amounts of terrestrial runoff and stream input leading to an extremely eutrophic environment during summer (Jiang \& Paul 1994), which probably provides an abundant food resource for the suspension feeding lancelets. The summer freshwater influx is not great enough to cause a catastrophic decline in salinity resulting in mass mortality as in the Lagos Lagoon (Webb 1958) and perhaps as in Kingston Harbor, Jamaica (McShine 1971). Pronounced reductions in salinity are known to cause massive population declines in Branchiostoma floridae living in Mississippi Sound, USA (Dawson 1965), and red tides associated with the toxic dynoflagellate Ptychodiscus brevis once caused mass mortality of $B$. floridae in Tampa Bay (Simon \& Dauer 1972). Also, during summer in Tampa Bay there is an order of magnitude greater viral abundance (Jiang \& Paul 1994) than in winter, although the exact effect this has on the ecosystem is not known. During an unusually cold winter in Europe, sustained low temperatures $\left(0^{\circ} \mathrm{C}\right.$ or slightly below, for 2 mol caused mass mortality in populations of B. lanceolatum in the North Sea (Courtney et al. 1964). However, in Tampa Bay, minimum temperatures (about $14^{\circ} \mathrm{C}$ ) are doubtlessly much too high to cause mass mortality. In fact, $B$. floridae adults can readily survive a $10 \mathrm{~h}$ exposure to $2.5^{\circ} \mathrm{C}$ in the laboratory (Stokes pers. obs.).

It was impossible to compare the calculated secondary production and production to biomass ratios (P:B) for Branchiostoma floridae with other cephalo- 
chordates which have not been studied in this respect. The maximum secondary production $161.53 \mathrm{~g} \mathrm{~m}^{-2} \mathrm{yr}^{-1}$ AFDW, $66.48 \mathrm{~g} \mathrm{~m}^{-2} \mathrm{yr}^{-1} \mathrm{DW}$ ) calculated by the massspecific growth method is not exceptional when compared to other benthic macrofaunal communities, which typically produce less than $150 \mathrm{~g} \mathrm{~m}^{-2} \mathrm{yr}^{-1} \mathrm{DW}$ (Vetter 1995). And likewise, a P:B ratio of 11.64 is not exceptionally high when one considers that this lancelet population is probably not resource limited.

The average cohort method (Eq. 11) and the massspecific growth method (Eq. 9) estimated secondary production values well within an order of magnitude of each other. In this instance the mass-specific growth estimate may be the more accurate since it does not rely on the subjective choice of a cohort production interval (Crisp 1971). Most methods for calculating secondary production yield only rough approximations and may underestimate or overestimate production depending on the particular circumstances (Waters \& Crawford 1973, Cushman et al. 1977). The calculated production is probably conservative for dense communities of Branchiostoma floridae. Pierce (1965) reported up to 183 ind. $\mathrm{l}^{-1}$ (or about 2800 ind $\mathrm{m}^{-2}$ ) nearby in Tampa Bay, and Bloom et al. (1972) reported a comparable density of lancelets (approx. 340 ind $\mathrm{m}^{-2}$ ) at the same location as the present study. McShine (1971) reported over 5000 ind. $\mathrm{m}^{-2}$ for B. floridae in Jamaica. As calculated from the population densities of Pierce and of McShine, secondary production would be 2 to 4.5 times greater than that reported here. In all studies, population densities were extremely variable, presumably because lancelets are capable of movement within the sand.

In the present study, the comprehensive data set allowed the ad hoc assessment of growth parameters without having to rely on regression analysis and fitting of growth functions, as is frequently done in studies based on a small number of samples. The comparison of the cohort data with the model functions illustrates possible problems that could arise from relying on model estimates of growth parameters when data is gathered at infrequent intervals during the life history. When considering growth for a given life history stage of a given species, it is not possible to extrapolate model parameters to other species, or to other life history stages of the same species. It may not even be appropriate to extrapolate model results, particularly of 'averaged' cross-sectional data, among different sampling times of the same population. It is important to analyze the data set and choose the correct growth model with consideration of organismal biology. For example, sessile or semi-sessile benthic organisms that live in environments (especially temperate ones) undergoing large seasonal fluctuations in temperature or nutrient supply likely to influence growth rates can only be accurately modelled by a growth function incorporating at least one simple seasonal oscillation such as the modifications to the von Bertalanffy function used here. This method may be applied to other simple growth models as well ie.g. seasonally modified Gompertz function in Sager \& Gosselck 1986) for those organisms following a more sigmoid intrinsic growth trajectory.

From the pattern of larval settlement into the benthic population of Branchiostoma floridae, it is apparent that the breeding for this lancelet in Tampa Bay lasts from approximately early May through early September each year. The tempo of settlement probably reflects the periodicity of spawning of adult populations in Tampa Bay. Lancelets in different parts of Tampa Bay tend to spawn in synchrony (Stokes unpubl. obs.) and spawning events are restricted to 1 or 2 nights in duration, from 7 to $20 \mathrm{~d}$ apart (Stokes unpubl. obs). Pierce (1965) could find no large populations of lancelets within $100 \mathrm{~km}$ north or south of the entrance to Tampa Bay; thus, there is probably no large-scale immigration of larvae of $B$. floridae from the nearby Gulf of Mexico. Residence times for water in the upper Tampa Bay have been estimated at between 10 and $120 \mathrm{~d}$ (N. Schmidt pers. comm.). Since the larvae of $B$. floridae spend from 3 to $4 \mathrm{wk}$ in the plankton before settling (Stokes \& Holland 1995a), the longer estimated residence times are probably closer to the true ones.

Tampa Bay has proven to be an excellent location for investigations of Branchiostoma floridae biology. The most conspicuous feature of $B$. floridae population ecology is the periodic settlement of large, discrete cohorts of recently metamorphosed juveniles. The $1 \mathrm{wk}$ to $10 \mathrm{~d}$ settlement of lancelets during late spring and summer is probably reflected in the tempo of adult spawning, such that this system provides an opportunity for future investigation of the physical and biological influences on larval survival and adult reproductive biology. Outstanding problems include: determining minimum size at sexual maturity; measuring fecundity; establishing whether individuals are semelparous or iteroparous; and identifying what physical or biological factors trigger the suspected epidemic spawnings.

Branchiostoma floridae living in Tampa Bay could also be advantageous for studying the difficult problem of the population dynamics of planktotrophic larvae. Tampa Bay is a partially closed hydrographic system into which lancelet larvae are injected in massive and discrete pulses. In addition, the developmental interval between fertilization and settlement (about $3 \mathrm{wk}$ ) is not unduly long. These features could make this a favorable system for testing methods (molecular or otherwise) for spatiotemporal marking cohorts of planktonic larvae. 
Acknowledgements. I thank J. M. Lawrence for graciously providing laboratory facilities during the course of this project. S. Miller for making important sieve collections during winter and spring 1993 and 1994, N. Schmidt for providing help accessing the PORTS data set, and all those people who helped measure the 54264 lancelets collected. L. Z. Holland, N. D Holland, P. K. Dayton and J. T. Enright provided thoughtful comments during the preparation of this manuscript.

\section{LITERATURE CITED}

Azariah J (1965) On the seasonal appearance of fin rays and their bearing on the reproductive cycle of Branchiostoma lanceolatum. J mar biol Ass India 7:459-461

Azariah $J$ (1994) Variations in the life span and growth rates within a population of amphioxus, Branchiostoma lanceolatum. J Morph 220:321-322

Benke AC (1979) A modification of the Hynes method for estimating secondary production with particular significance for multivoltine populations. Limnol Oceanogr 24:171-176

Berril NJ (1955) The origin of the vertebrates. Clarendon Press, Oxford

Bloom JL, Simon SA, Hunter VD (1972) Animal-sediment relations and community analysis of a Florida estuary. Mar Biol 13:43-56

Brey T, Arntz WE, Pauly D, Rumohr H (1990) Arctica (Cyprina) islandica in Kiel Bay (Western Baltic): growth, production and ecological significance. J exp mar Biol Ecol 136:217-235

Chen Y, Jackson DA, Harvey HH (1992) A comparison of von Bertalanffy and polynomial functions in modelling fish growth data. Can J Fish aquat Sci 49:1228-1235

Chin TG (1941) Studies on the biology of the Amoy amphioxus Branchiostoma belcheri Gray. Philipp J Sci 75:369-421

Clasing E, Brey T, Stead R, Navarro J, Asencio G (1994) Population dynamics of Venus antiqua (Bivalvia: Veneracea) in the Bahía de Yaldad, Isla de Chiloé, Southern Chile. J exp mar Biol Ecol 177:171-186

Cloern JE, Nichols FH (1978) A von Bertalanffy growth model with a seasonally varying coefficient. J Fish Res Bd Can $35: 1479-1482$

Courtney WAM (1975) The temperature relationships and age-structure of North Sea and Mediterranean populations of Branchiostoma lanceolatum. Symp zoo Soc Lond 36:213-233

Courtney WAM, Webb JE (1964) The effects of the cold winter of $1962 / 63$ on the Helgoland population of Branchiostoma lanceolatum (Pallas). Helgoländer wiss Meeresunters 10:301-312

Crisp DJ (1984) Energy flow measurements. In: Holme NA, McIntyre AD (eds) Methods for the study of marine benthos. Blackwell Scientific Publications, Oxford, p 197-279

Cushman RM, Shugart HH, Hildebrand SG, Elwood JW (1977) The effect of growth curve and sampling regime on instantaneous-growth, removal-summation, and Hynes/ Hamilton estimates of aquatic insect production: a computer simulation. Limnol Oceanogr 23:184-189

Dawson CE (1965) Rainstorm induced mortality of lancelets, Branchiostoma, in Mississippi Sound. Copeia 1965: 505-506

Fournier DA, Sibert JR, Majkowski J, Hampton J (1990) MULTIFAN a likelihood-based method for estimating growth parameters and age composition from multiple length frequency data sets illustrated using data for southern bluefin tuna (Thunnus maccoyii). Can J Fish aquat Sci $47: 301-317$
Frankenberg D (1968) Seasonal aggregation in amphioxus. Bioscience 18:877-878

Futch CR, Dwinell SE (1977) Nearshore marine ecology at Hutchinson Island, Florida: 1971-1974. IV Lancelets and fishes. Fla mar res Publ 24:1-23

Gans C (1989) Stages in the origin of vertebrates: analysis by means of scenarios. Biol Rev 64:221-268

Garcia-Fernàndez J, Holland PWH (1994) Archetypal organization of the amphioxus Hox gene cluster. Nature 370 : $563-566$

Gosselck F, Spittler P (1979) Age structure, growth, and weight of Branchiostoma senegalense (Acrania, Branchiostomidae) off North-West Africa. Int Revue ges Hydrobiol 64:541-550

Hamilton AL (1969) On estimating annual production. Limnol Oceanogr 14:771-782

Harding JP (1949) The use of probability paper for the graphical analysis of polymodal frequency distributions. J mar biol Ass UK 28:141-153

Holland ND, Holland LZ (1989) Fine structural study of the cortical reaction and formation of the egg coats in a lancelet (= amphioxus), Branchiostoma floridae (phylum Chordata: subphylum Cephalochordata $=$ Acrania $)$. Biol Bull 176:111-122

Holland ND, Holland LZ (1991) The histochemistry and fine structure of the nutritional reserves in the fin rays of a lancelet, Branchiostoma lanceolatum (Cephalochordata = Acrania). Acta zool Stockh 72:203-208

Holland PWH, Holland LZ, Williams NA, Holland ND (1992) An amphioxus homeobox gene: sequence conservation, spatial expression during development and insights into vertebrate evolution. Development (Camb) 116:653-661

Jiang SC, Paul JH (1994) Seasonal and diel abundance of viruses and occurrence of lysogeny/bacteriocinogeny in the marine environment Mar Ecol Prog Ser 104:163-172

Kaufmann KW (1981) Fitting and using growth curves Oecologia 49:293-299

Lumingas LJL, Guillou M (1994) Growth zones and backcalculation for the sea urchin, Spaerechinus granularis, from the Bay of Brest, France. J mar biol Ass UK 74: $671-686$

MacDonald PDM, Pitcher TJ (1979) Age-groups from size-frequency data: a versatile and efficient method of analyzing distribution mixtures. J Fish Res Bd Can 36:987-1001

McShine AH (1971) Some aspects of the biology of Brachiostoma caribaeum Sundevall (Cephalochordata) in Kingston Harbour, Jamaica. MS thesis, University of the West Indies, Kingstor

Nelson G (1969) Amphioxus in old Tampa Bay, Florida. Q J Fl Acad Sci 31:93-100

Pierce EL (1965) The distribution of lancelets (amphioxi) along the coasts of Florida. Bull mar Sci 15:480-494

Poss S, Boschung HT (1994) How many lancelets are there anyway? J Morph 220:382

Press WH, Teukolsky SA, Vetterling WT, Flannery BP (1988) Numerical recipes in $C$ : the art of scientific computing. Cambridge University Press, New York

Ricker WE (1979) Growth rates and models. In: Hoar WS, Randall DJ (eds) Fish physiology, Vol 8. Academic Press, New York, p $677-743$

Roa R (1993) Annual growth and maturity function of the squat lobster Pleuroncodes monodon in central Chile. Mar Ecol Prog Ser 97:157-166

Sager G, Gosselck F (1985) A contribution to the age-structure of Branchiostoma lanceolatum. Int Revue ges Hydrobiol 70:613-617 
Sager G, Gosselck F (1986) lnvestigation into seasonal growth of Branchiostoma lanceolatum off Helgoland, according to data by Courtney (1975). Int Revue ges Hydrobiol 71. $701-707$

Simon JL (1974) Tampa Bay estuarine system - a synopsis. Fla Scient 37:217-244

Simon JL, Dauer DM (1972) A quantitative evaluation of redtide induced mass mortalities of benthic invertebrates in Tampa Bay, Florida. Environ Lett 3: 229-234

Sokal RR, Rohlf FJ (1981) Biometry, 2nd edn. WH Freeman \& Co, New York

Sprung M (1995) Physiological energetics of the zebra mussel Dreissena polymorpha in lakes. I. Growth and reproductive effort. Hydrobiologia 304:117-132

Stokes MD, Holland ND (1995a) Embryos and larvae of a lancelet, Branchiostoma floridae, from hatching through metamorphosis - growth in the laboratory and external morphology. Acta Zool Stockh 76:105-120

Stokes MD, Holland ND (1995b) Ciliary hovering in larval lancelets (= amphioxus). Biol Bull 188:231-233

Systat (1992) SYSTAT: statistics, version 5.2. Systat Inc, Evanston

Vetter EW (1995) Detritus-based patches of high secondary

This article was presented by N. D. Holland (Senior Editorial Advisor), La Jolla, California, USA production in the nearshore benthos. Mar Ecol Prog Ser 120:251-262

von Bertalanffy $\mathcal{L}$ (1938) A quantitative theory of organic growth (inquiries on growth laws II). Hum Biol 10: $181-213$

Wada H, Satoh N (1994) Details of the evolutionary history of invertebrates to vertebrates as deduced from sequence 18S rRNA. Proc natl Acad Sci USA 91:1801-1804

Waters TF, Crawford GW (1973) Annual production of a steam mayfly population: a comparison of methods. Limnol Oceanogr 18:286-296

Webb JE (1958) The ecology of Lagos Lagoon. III. The life history of Branchiostoma nigeriense Webb. Phil Trans R Soc Lond Ser B 241:335-343

Wells MM (1926) Collecting amphioxus. Science 64: $187-188$

Willey A (1894) Amphioxus and the ancestry of the vertebrates. MacMillan, New York

Wu XQ, Zhang SC, Wang YY, Zhang BL, Qu YM, Jiang XJ (1994) Laboratory observation on spawning, fecundity and larval development of amphioxus (Branchiostoma belcheri Tsingtaunese). Chin J Oceanol Limnol 12: $289-294$

Manuscript first received: June 1, 1995

Revised version accepted: July 11, 1995 